\title{
Beware the person with the glass eye and the large liver
}

\author{
Edith Vassallo, ${ }^{1}$ Christine Azzopardi, ${ }^{2}$ Richard Pullicino, ${ }^{1}$ Reuben Grech ${ }^{1}$
}

${ }^{1}$ Department of Medical Imaging, Mater Dei Hospital Malta, Msida, Malta

${ }^{2}$ Mater Dei Hospital, Msida, Malta

\section{Correspondence to} Dr Edith Vassallo, edithvassallo@gmail.com

Accepted 23 April 2014

\section{DESCRIPTION}

A 67-year-old woman presented to the emergency department reporting of epigastric fullness, fatigue and weight loss.

Physical examination revealed three fingerbreadths of hepatomegaly. Blood tests were unremarkable, save for a moderately raised erythrocyte sedimentation rate.

An urgent CT of her abdomen demonstrated two large liver lesions of low attenuation on the non-enhanced scan (figure 1A), showing heterogeneous enhancement in the arterial phase (figure 1B) with contrast washout after a 5 min delay (figure 1C), an appearance typical of hypervascular metastasis. Ultrasound-guided biopsy of one of these lesions was performed as a primary tumour was not identified. This revealed metastatic melanoma, however the primary lesion was not apparent on clinical examination.
At a follow-up appointment the patient admitted to progressively worsening headaches. Non-contrast CT scan of the brain excluded any space-occupying lesions. A solid hyperdense mass was however identified at the posteroinferior aspect of the left lobe.

MRI revealed a well-defined, homogenous, intraorbital mass with intrinsic hyperintensity on $\mathrm{T} 1$ and fluid-attenuated inversion recovery (figure 2A), showing avid enhancement postcontrast (figure 2B, C). There was no evidence of extraocular extension or associated retinal detachment. Given the advanced stage of the tumour, she was treated conservatively with systemic chemotherapy and symptomatic pain relief and is currently being followed up regularly by the oncology team. The imaging findings described are characteristic of malignant uveal melanoma which is the most common primary intraocular malignancy in adults and the second commonest

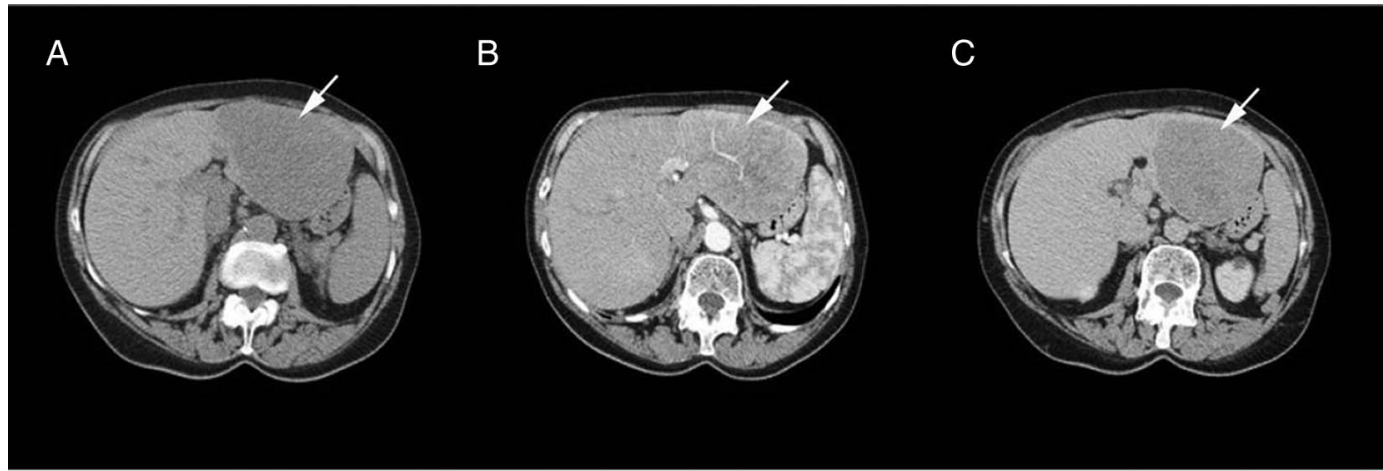

Figure 1 (A) Unenhanced CT of the abdomen. A large hypoattenuating lesion in the left lobe of the liver is seen. (B) Postcontrast CT scan of the abdomen in the arterial phase. Heterogenous enhancement is seen. (C) Delayed phase scan at $5 \mathrm{~min}$. The lesion is of lower attenuation compared to normal liver consistent with washout.

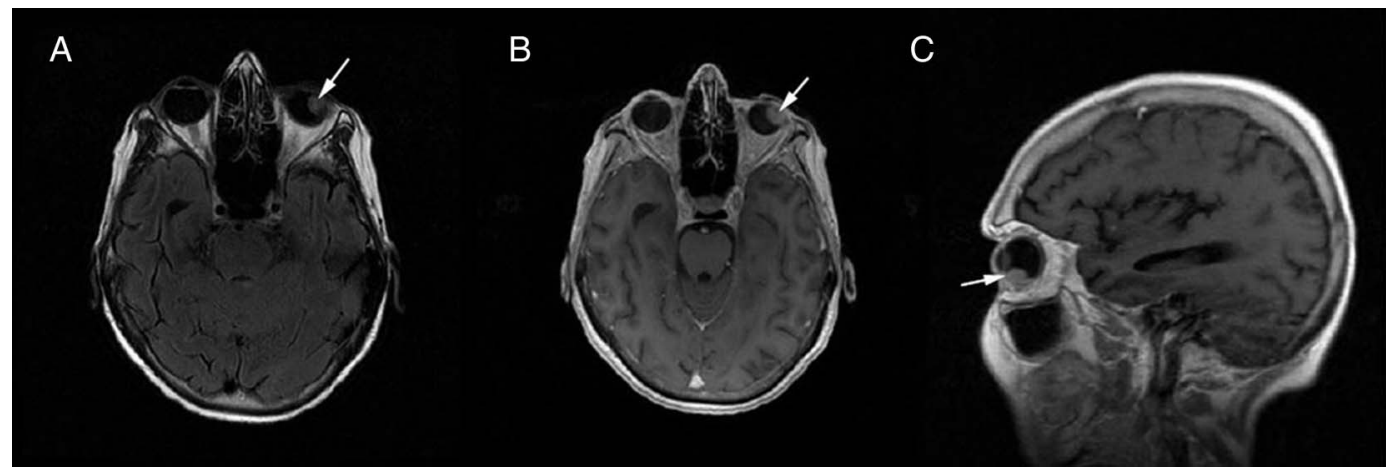

Azzopardi C, Pullicino R, et al. BMJ Case Rep Published online: [please include Day Month Year] doi:10.1136/bcr-2014 204563

Figure 2 (A) Axial fluid-attenuated inversion recovery sequence: solid lesion arising from the outer posteroinferior aspect of the left lobe. (B) Axial T1-weighted sequence following intravenous gadolinium administration showing significant enhancement. (C) Postcontrast sagittal T1-weighted sequence. The lesion is well defined with no associated retinal detatchment or extraocular extension. 
ocular malignancy following metastasis. ${ }^{1}$ The presence of metastasis heralds a poor prognosis. ${ }^{2}$

\section{Learning points}

- Malignant uveal melanoma is the most common primary intraocular malignancy in adults and the second commonest ocular malignancy following metastasis.

- The presence of metastasis in patients with malignant uveal melanoma heralds a poor prognosis.

- Melanoma has a characteristic appearance on MRI due to its melanin content demonstrating high signal on T1 and low signal on $\mathrm{T} 2$ contrary to other tumours.
Contributors $\mathrm{EV}$ is the guarantor of integrity of the case report and was involved in the literature research. RG, EV and CA were involved in manuscript preparation. $\mathrm{RG}$ and $\mathrm{RP}$ were involved in manuscript editing.

Competing interests None.

Patient consent Obtained.

Provenance and peer review Not commissioned; externally peer reviewed.

\section{REFERENCES}

1 Tong KA, Osborn AG, Mamalis N, et al. Ocular melanoma AJR Am J Roentgenol 1993:14:1359-66.

2 Lorigan JG, Wallace S, Mavlight GM. The prevalence and location of metastases from ocular melanoma: imaging study in 110 patients. AJR Am J Roentgenol 1991;157:1279-81.

Copyright 2014 BMJ Publishing Group. All rights reserved. For permission to reuse any of this content visit http://group.bmj.com/group/rights-licensing/permissions.

BMJ Case Report Fellows may re-use this article for personal use and teaching without any further permission.

Become a Fellow of BMJ Case Reports today and you can:

- Submit as many cases as you like

- Enjoy fast sympathetic peer review and rapid publication of accepted articles

- Access all the published articles

- Re-use any of the published material for personal use and teaching without further permission

For information on Institutional Fellowships contact consortiasales@bmjgroup.com

Visit casereports.bmj.com for more articles like this and to become a Fellow 